MENTORING \& TUTORING: Partnership in Learning

VOLUME 23 NUMBER 5 NOVEMBER 2015

Special Issue: Undergraduate Research Mentoring

Guest Editors: Laura L. Behling, W. Brad Johnson, Paul Miller and Maureen Vandermaas-Peeler

CONTENTS

Introduction

Guest Editors' Overview: Undergraduate Research Mentoring

Laura L. Behling, W. Brad fohnson, Paul Miller and

Maureen Vandermaas-Peeler

Articles

Ten Salient Practices of Undergraduate Research Mentors: A Review of the Literature

fenny Olin Shanahan, Elizabeth Ackley-Holbrook, Eric Hall,

Kearsley Stewart and Helen Walkington

"Mentoring is Sharing the Excitement of Discovery": Faculty

Perceptions of Undergraduate Research Mentoring

Maureen Vandermaas-Peeler, Paul C. Miller and Tim Peeples

Faculty as Mentors in Undergraduate Research, Scholarship, and Creative Work: Motivating and Inhibiting Factors

Vicki L. Baker, Meghan 7. Pifer, Laura G. Lunsford, Fane Greer and Dijana Ihas

Mentoring, Undergraduate Research, and Identity Development: A Conceptual Review and Research Agenda

Ruth F. Palmer, Andrea N. Hunt, Michael Neal and Brad Wuetherick

Mentoring Undergraduate Scholars: A Pathway to Interdisciplinary Research?

Shannon N. Davis, Duhita Mahatmya, Pamela W. Garner and Rebecca

M. fones

Undergraduate Research Mentoring: Obstacles and Opportunities W. Brad Fohnson, Laura L. Behling, Paul Miller and

Maureen Vandermaas-Peeler

Routledge

Taylor \& Francis Group
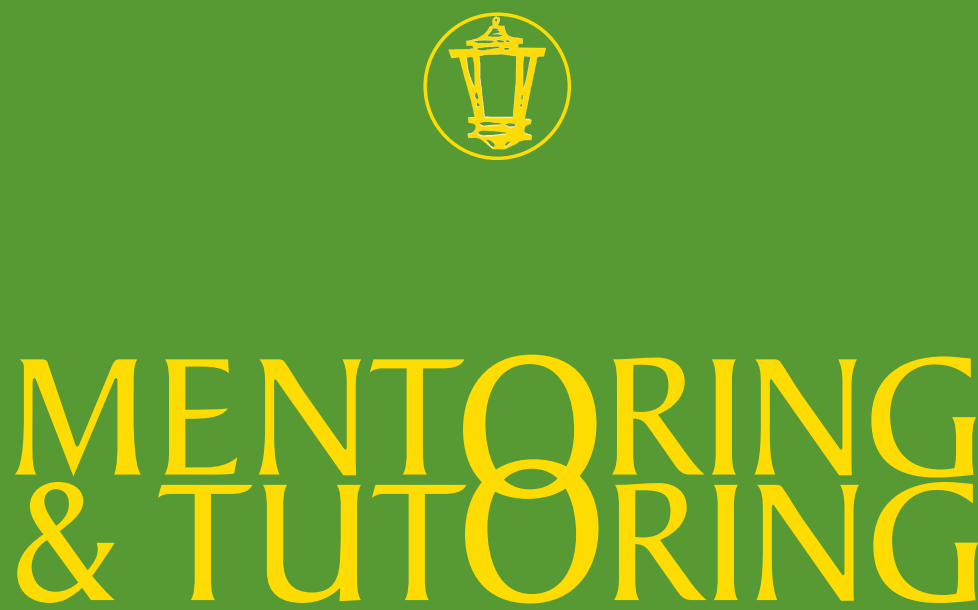

Partnership in Learning

Beverly I. Irby, Editor

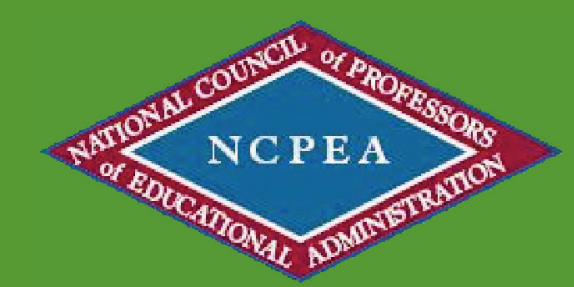




\section{Ten Salient Practices of Undergraduate Research Mentors: A Review of the Literature}

Jenny Olin Shanahan, Elizabeth Ackley-Holbrook, Eric Hall, Kearsley Stewart \& Helen Walkington

To cite this article: Jenny Olin Shanahan, Elizabeth Ackley-Holbrook, Eric Hall, Kearsley Stewart \& Helen Walkington (2015): Ten Salient Practices of Undergraduate Research Mentors: A Review of the Literature, Mentoring \& Tutoring: Partnership in Learning, DOI: 10.1080/13611267.2015.1126162

To link to this article: http://dx.doi.org/10.1080/13611267.2015.1126162

曲 Published online: 28 Dec 2015.

Submit your article to this journal $\asymp$

a

View related articles $\asymp$

View Crossmark data $₫$ 


\title{
Ten Salient Practices of Undergraduate Research Mentors: A Review of the Literature
}

\author{
Jenny Olin Shanahan \\ Bridgewater State University \\ Elizabeth Ackley-Holbrook \\ Roanoke College \\ Eric Hall \\ Elon University \\ Kearsley Stewart \\ Duke University \\ Helen Walkington \\ Oxford Brookes University
}

\begin{abstract}
This paper identifies salient practices of faculty mentors of undergraduate research (UR) as indicated in the extensive literature of the past two decades on UR. The well-established benefits for students involved in UR are dependent, first and foremost, on high-quality mentoring. Mentorship is a defining feature of UR. As more and different types of colleges and universities strive to meet student demand for authentic scholarly experiences, it is imperative to identify what effective UR mentors do in order to ensure student engagement, quality enhancement, retention, and degree-completion. We offer an original analysis of the literature on UR mentoring in which we identify 10 significant "lessons learned," or evidence-based practices of effective UR mentors that apply broadly across disciplines, students, institutions, and mentoring approaches.
\end{abstract}

Keywords: undergraduate research, mentoring, practices, peer mentoring, quality enhancement

Nearly two decades ago, the Boyer Commission proposed 10 recommendations for improving undergraduate education at research universities in the USA (Boyer Commission on Educating Undergraduates in the Research University, 1998). The first recommendation, "Make Research-based Learning the Standard," ignited the movement in the USA to include undergraduates in faculty research, both to advance faculty research agendas and to foster students' critical thinking, analysis, and communication skills. Following the Boyer Commission's lead, by the late 1990s, US research organizations, such as the Howard Hughes Medical Institute, National Institutes of Health, and National

Jenny Olin Shanahan, Bridgewater State University; Elizabeth Ackley-Holbrook, Roanoke College; Eric E. Hall, Elon University; Kearsley Stewart, Duke University; Helen Walkington, Oxford Brookes University.

Correspondence concerning this article should be addressed to Jenny Olin Shanahan, Bridgewater State University. E-mail: Jenny.Shanahan@bridgew.edu. 
Science Foundation, funded opportunities to integrate undergraduates into the research programs of science faculty. At a smaller scale, the Andrew Mellon Foundation supported programming for undergraduates to participate in humanities scholarly work at liberal arts colleges. Over the next decade, numerous studies conducted in the USA, the UK, and Canada clearly demonstrated the benefits of involving undergraduates in research (Gillies \& Marsh, 2013; Graham, Hempstead, \& Couchman, 2012; Healey \& Jenkins, 2009; Hensel, 2012; Kuh, 2008; Lopatto, 2010). Now recognized as a global phenomenon (Jenkins \& Healey, 2010), the integration of research and teaching at the undergraduate level is taking hold in Australasia (Healey \& Jenkins, 2009; Sandover, Partridge, Dunne, \& Burkill, 2012), China (Wang \& Wang, 2008; Yuhao, 2014), India (Padmaja, Laxmi Ramana, \& Reddy, 2015), the Middle East (Alamodi et al., 2014; Ibnouf, Dou, \& Knight, 2014), and the Netherlands (van der Rijst \& Visser-Wijnveen, 2011), among other parts of the world. Both government and private funding drive the transformation of undergraduate education in countries such as Oman (Oman Research Council), Qatar (Qatar National Research Fund), and China (Yuhao, 2014). The first "World Congress" of Undergraduate Research (UR) is scheduled for November 2016 at Qatar University.

The identification of UR as a high-impact practice by the Association of American Colleges and Universities added fuel to this global movement (Kuh, 2008). As institutions in the USA have sought to improve rates of retention, degree completion, and graduate/professional-school acceptance, high-impact practices (HIPs, as they have come to be known) have received greater attention - and none more so than UR (Elgren \& Hensel, 2006; Elrod, Husic, \& Kinzie, 2010; Kuh \& O’Donnell, 2013; Lopatto, 2010). Data suggesting that UR offers particular gains for students from under-served populations (Brownell \& Swaner, 2010; Gandara \& Maxwell-Jolly, 1999; Gregerman, 2009; Kinzie, Gonyea, Shoup, \& Kuh, 2008), along with US funding commitments to diversity in research (e.g. McNair Scholarships, National Science Foundation supplemental funding for underrepresented students), have also stimulated broader participation. The growth of UR has brought about significant changes in its practice in the last decade:

- expansion of UR beyond laboratory sciences - to mathematics, social sciences, arts and humanities, and professional disciplines (Crawford, Orel, \& Shanahan, 2014; DeVries, 2001; FitzGerald \& Midiri, 2013; Johnson \& Harreld, 2012; Klos, Shanahan, \& Young, 2011; Levenson, 2010; McDorman, 2004; Schantz, 2008; Shanahan et al., 2015) - and, with that expansion, use of the term "Undergraduate Research, Scholarship, and Creative Activity," or URSCA (Crawford \& Shanahan, 2014; Osborn \& Karukstis, 2009);

- availability of UR opportunities in an array of institution types, including community colleges in the USA (Brandt \& Hayes, 2012; Hensel \& Cejda, 2014; Thorsheim, LaCost, \& Narum, 2010) and further-education colleges in the UK (Healey, Jenkins, \& Lea, 2014);

- broader UR experiences that include not only the traditional apprenticeship model with an individual professor, but also more democratic, course-based experiences (including online courses) that involve diverse groups of students in scholarly work (Brush, Cox, Harris, \& Torda, 2010; Corwin, Graham, \& Dolan, 2015; Kasprisin, Boyle Single, Single, \& Muller, 2003). 
Even with significant changes in how scholarly opportunities are provided for students, at least one facet remains constant: effective mentoring is essential to the success of UR (Kuh, 2008; National Academy of Sciences, National Academy of Engineering, Institute of Medicine [NAS], 1997; Osborn \& Karukstis, 2009; Wenzel, 1997). The benefits students gain from participating in UR depend on the quality of the mentoring they receive (Bowman \& Stage, 2002; Hensel, 2012; Ishiyama, 2007; Jones \& Davis, 2014; Linn, Palmer, Baranger, Gerard, \& Stone, 2015; Mekolichick \& Gibbs, 2012; National Academy of Sciences, National Academy of Engineering, Institute of Medicine, 1997; Pfund, Pribbenow, Branchaw, Miller-Lauffer, \& Handelsman, 2006). Research shows the need for, and the benefits of, personally-supportive UR mentoring across a variety of contexts, including different demographic groups (e.g. nontraditional undergraduates, first-generation students), academic disciplines, and underrepresented groups (e.g. women in STEM fields, minority students) (Bowman \& Stage, 2002; Brownell \& Swaner, 2010; Gregerman, 2009; Guterman, 2007; Jones, Barlow, \& Villarejo, 2010; Kendricks, Nedunuri, \& Arment, 2013; Locks \& Gregerman, 2008; Osborn \& Karukstis, 2009). Despite the need for strong UR mentors, overarching guidelines on what makes for "good" mentoring do not exist. Much of what can be learned about effective practices is based on faculty self-reports and student perspectives on what they favored about their mentors. Other mentoring practices can be inferred from the broader literature about what makes UR successful; e.g. because students gain confidence and oral-communication skills from presenting their work at conferences (Mabrouk, 2009; Mekolichick \& Bellamy, 2012), one can surmise that effective mentoring includes taking students to conferences and helping them prepare for presentations.

Reports on the particular attitudes and concrete practices of successful UR mentors often come from faculty sharing their own experiences in particular, disciplinary settings (Cooley, Garcia, \& Hughes, 2008; Laursen, Hunter, Seymour, Thiry, \& Melton, 2010; Shore, 2005; Wayment \& Dickson, 2008). Although such self-reporting on effective mentoring is often anecdotal and based on small numbers of student participants, it nonetheless presents an opportunity for identifying patterns of behaviors and attitudes in mentoring relationships deemed successful by those involved in them. Similar limitations associated with self-reporting - as well as similar opportunities for examining patterns of responses - exist in student surveys about the mentoring they have received. While students may be able to speak about effective (or ineffective) practices only in terms of their own mentors, themes can be inferred from student survey data from different types of institutions and academic disciplines. A comprehensive analysis of patterns in the literature pertaining to UR mentoring has not been carried out, however. This review identifies from over 100 peer-reviewed articles what makes for successful UR mentoring, in order to inform and support faculty mentors and the administrators who recruit, train, and help sustain them.

\section{Method}

Five scholars who mentor undergraduate researchers in different disciplines and different types of institutions in the USA and the UK conducted this narrative review of the literature. Each identified, read, and analyzed peer-reviewed articles and books located through EBSCO and ERIC databases and the CUR Quarterly and Perspectives on Undergraduate Research and Mentoring websites with keywords "undergraduate 
research," "mentor," "mentoring," "best practices," "strategies," and "challenges." Keywords were adjusted throughout the process to isolate articles that explicitly addressed mentoring practices. References from preliminary articles were used to identify further pertinent literature. Each of the five researchers focused on a pre-identified area of the literature, which frequently overlapped with one another: (a) general "best practices" of mentoring undergraduates, (b) faculty in various disciplines sharing what they do in mentoring UR, (c) student survey and interview data about the mentoring they received, (d) particular mentoring needs of underrepresented students, and (e) peer and graduatestudent/postdoc mentoring of UR. Through this review, 10 practices emerged as widely effective. Each practice fit within the broad context of support that Thiry and Laursen (2011) deemed as integral components of UR mentoring: intellectual support, personal/ emotional support, and professional socialization. Intellectual support refers to helping "with problem-solving or identifying the 'next steps' of the experiment" (p. 776); a mentor provides personal/emotional support by being "supportive, accessible, friendly, and [by taking] an interest in [students]" (p. 776); and professional socialization support includes "transmitting the values and norms of the profession, along with essential disciplinary knowledge and skills" (p. 775).

The 10 practices identified through this review serve to form a pedagogy of mentored UR (see Table 1). The practices are identified in the approximate order in which faculty would engage in mentoring undergraduate researchers, with an understanding that the stages of planning, researching, and disseminating the findings are iterative and not directly linear.

\section{Salient Mentoring Practices}

\section{Salient Practice \#1: Engage in Strategic Pre-planning}

The first salient practice of UR mentoring is to do strategic pre-planning in order to be ready to respond to students' varying needs and abilities throughout the research process. Several scholars have noted that in order to help undergraduates develop research and

Table 1

Ten Salient Practices of Undergraduate Research Mentors

1. Do strategic pre-planning in order to be ready to respond to students' varying needs and abilities throughout the research process.

2. Set clear and well-scaffolded expectations for undergraduate researchers.

3. Teach the technical skills, methods, and techniques of conducting research in the discipline.

4. Balance rigorous expectations with emotional support and appropriate personal interest in students.

5. Build community among groups of undergraduate researchers and mentors, including graduate students, postdoctoral fellows, and any other members of the research team.

6. Dedicate time as well to one-on-one, hands-on mentoring.

7. Increase student ownership of the research over time.

8. Support students' professional development through networking and explaining norms of the discipline.

9. Create intentional, laddered opportunities for peers and "near peers" to learn mentoring skills and to bring larger numbers of undergraduates into scholarly opportunities.

10. Encourage students to share their findings and provide guidance on how to do so effectively in oral and poster presentations and in writing. 
communication skills, it is important to take into consideration the wide variability in their levels of preparation, motivation, and skills, and to be ready to guide their progress closely (Lown, 1993; Mabrouk \& Peters, 2000; Malachowski, 1996; Merkel \& Baker, 2002; Schultz, 2001; Shore, 2005). Laursen et al. (2010) suggested that mentors manage the different needs and abilities of students by giving extensive consideration to project selection and planning. They identified four characteristics of a good UR project: (a) "Must start at a theoretical level that undergraduates are capable of understanding, given their year in school and course background"; (b) "Must draw on skills that students already possess or can learn quickly enough, to give them a chance to progress in the time available"; (c) "Should have a modest scope that can be either simplified or extended"; and (d) "Should have a good chance of producing results within the time frame available" (p. 148).

Planning the timetable for UR was recommended by Cox and Androit (2009) as well, as they found that bringing students into a research team early and planning for long-term collaboration served the mentor as well as the students. More progress could be made on the research when mentors invested time early in the process to plan and get organized. Undergraduates also became more invested in research projects over time and accomplished more the longer they participated (Cox \& Androit, 2009). Alternatively, the authors found that engagement for a short period of time (i.e. one semester or summer) did not adequately prepare students to understand and investigate a research topic, despite positive interactions with a mentor (Cox \& Androit, 2009).

While on the one hand researchers have recommended giving careful consideration to the feasibility and timeline of a proposed project for undergraduates, they have also implied that mentors should not underestimate students' ability to do authentic scholarship. Mentors have been urged to include students in work that makes a unique contribution to the discipline and offers student-researchers authentic research experiences - i.e. those that prompt students to think about and try to solve real problems (Craig, 1999; Laursen et al., 2010; Merkel \& Baker, 2002; Shellito, Shea, Mueller-Solger, \& Davis, 2001; Shore, 2005). The implication for mentors' practices in these studies is to prepare for successful undergraduate-research experiences long before the actual research commences, evaluating the proposed project's feasibility, scope, significance in the discipline, and potential for student engagement in authentic problem-solving.

\section{Salient Practice \#2: Set Clear and Well-Scaffolded Expectations}

The second salient practice to emerge from the literature is to set clear and well-scaffolded expectations of undergraduate researchers. Malachowski (1996) noted that once research is underway mentors need to be sensitive to how much guidance or structure different students require. Students' needs fluctuate at various points in the project; those in the initial stages of research often need more hands-on mentoring than they will at later points (Malachowski, 1996; Merkel \& Baker, 2002; Schultz, 2001). Likewise, Moore, Dueweke, Newton, and Stevens-Russ (2005) called for scaffolded research assignments, which build in strong mentor support in the early phase of the project and gradually lead to more student independence.

To facilitate a scaffolded approach, Mabrouk (2003) recommended that mentors jointly create clear, structured plans and outline their expectations through learning contracts with students. Abdel-Qader (2004) said that students conducting research for 
credit (e.g. as an independent study) should be given a syllabus, just as in a traditional course, which clearly lays out goals and expectations of the work. In addition to expectations related to research protocols and outcomes, several authors have noted the importance of outlining expectations related to interpersonal dynamics (Gray, 2000; Lown, 1993; Merkel \& Baker, 2002; Shellito et al., 2001; Shore, 2005). In this way, students gain a better understanding of what is required regarding roles and interactions among the team members and how their work will be evaluated.

\section{Salient Practice \#3: Teach Technical Skills, Methods, and Techniques}

The third salient practice of UR mentoring is teaching technical skills, methods, and techniques. Once the preparations have been made and expectations for the work are established and communicated, effective mentors start instructing students in research procedures. Several articles have pointed out that teaching students the technical skills, methods, and techniques necessary to conduct scholarly work in the discipline is the mentor's primary responsibility (Benson, 2002; Bowman \& Stage, 2002; Gafney, 2005; Lown, 1993; Merkel \& Baker, 2002; Shore, 2005). Concurrently, mentors should emphasize the importance of engaging in research in a safe and ethical manner (Benson, 2002; Lown, 1993; Merkel \& Baker, 2002). Depending on the discipline and the nature of the project, this more technical practice might include instruction related to following laboratory experiment protocols, navigating pertinent databases, utilizing studio equipment, accessing archival sources, and/or operating computational software. The intended skill set not only varies by discipline and scholarly purpose, but according to Schultz (2001), should also be personalized and intentionally suited to a student's goals.

\section{Salient Practice \#4: Balance Rigorous Expectations with Emotional Support and Appropriate Personal Interest in Students}

Fourth, UR mentors are advised in the literature to balance rigorous expectations of undergraduate researchers with emotional support and appropriate personal interest. Several authors have concluded that mentors' positive and constructive feedback to undergraduate researchers is critical to student success (Gray, 2000; National Academy of Sciences, National Academy of Engineering, Institute of Medicine, 1997; Shellito et al., 2001). Especially when students make first attempts at writing about research and presenting the results of their work, Shellito et al. (2001) noted that mentors' encouragements can significantly ease student anxiety and lack of self-esteem. Several researchers have pointed out that a UR experience represents the first time most students have engaged in scholarly research, emphasizing the need for mentors to be approachable and available to students (Gafney, 2005; Mabrouk \& Peters, 2000; Shellito et al., 2001; Shore, 2005).

Mentors have been advised to make concerted efforts to get to know studentresearchers as individuals to help meet their emotional needs as well as their learning requirements (Craig, 1999; Gray, 2000; Mabrouk \& Peters, 2000; National Academy of Sciences, National Academy of Engineering, Institute of Medicine, 1997; Shellito et al., 2001; Shore, 2005). In fact, an early text on UR mentoring was titled Adviser, Teacher, Role Model, Friend: On Being a Mentor to Students in Science and Engineering (National Academy of Sciences, National Academy of Engineering, Institute of 
Medicine, 1997). A text used in dozens of UR programs in the USA, Entering Mentoring: A Seminar to Train a New Generation of Scientists, holds as one of its three goals to guide mentors to "build a relationship based on trust and respect" with undergraduate researchers (Handelsman, Pfund, Lauffer, \& Pribbenow, 2005, p. 9). The seminar materials provide several specific ideas for fostering appropriate personal relationships with UR mentees, including engaging in "simple joint activities" such as attending lectures together (p. 44).

Several authors recounting students' perspectives on the mentoring they received have corroborated the importance of social-emotional support (Behar-Horenstein, Roberts, \& Dix, 2010; Falconer \& Holcomb, 2008; Hakim, 1998; Ishiyama, 2007; Kardash, 2000; Mabrouk \& Peters, 2000; Mekolichick \& Gibbs, 2012; Shellito et al., 2001; Showman, Cat, Cook, Holloway, \& Wittman, 2013; Yaffe, Bender, \& Sechrest, 2012). Falconer and Holcomb (2008) reported that students valued the affective and relational components of a mentored research experience more than measurable learning activities and outcomes. In several studies, students have placed the most value on mentor practices that foster deep student-faculty relationships and consider the following mentor traits vital to a successful UR experience: high level of availability (regular meetings), trustworthiness, capacity for network development beyond their own academic department, and ability to guide students through the research and writing process (Falconer \& Holcomb, 2008; Gafney, 2005; Lopatto, 2004; Mekolichick \& Gibbs, 2012; Shellito et al., 2001).

In comparing attitudes of first-generation and continuing-generation students (i.e. students from college-educated families), some researchers found that first-generation students distinctly emphasized pragmatic needs, such as career and graduate-school planning, over affective needs, whereas continuing-generation students primarily valued factors related to the student-mentor relationship (Ishiyama, 2007; Mekolichick \& Bellamy, 2012; Mekolichick \& Gibbs, 2012). For example, continuing-generation students placed higher importance on their mentor's friendliness than did first-generation students, who prioritized expertise and rated friendliness as the least important among several mentor traits (Ishiyama, 2007; Mekolichick \& Bellamy, 2012; Mekolichick \& Gibbs, 2012). However, first- and continuing-generation students reported accessibility and communication skills as very important (Ishiyama, 2007; Mekolichick \& Bellamy, 2012; Mekolichick \& Gibbs, 2012), suggesting that even students with pragmatic needs for mentor expertise want that expertise communicated by open, approachable mentors.

Social-emotional support of mentors has been shown to be even more important for underrepresented minority students involved in UR than for their peers in the majority. Students of color have emphasized more often than White students the value of personal connections with and emotional support from their UR mentors (Davis, 2007; Ishiyama, 2007; Kendricks et al., 2013; Mekolichick \& Gibbs, 2012; Schwartz, 2011). Whereas White students highlighted how mentors could help them get started in their careers, such as by helping them network in the field, students of color emphasized the importance of just having a faculty mentor whom they could trust. For underrepresented minority students, the "affective and interpersonal nature of the UR relationship may be just as significant as the academic" (Schwartz, 2011, p. 537). Schwartz (2011) explained that UR mentors of students of color who provide "emotional output, listening, [...] empathy, and [...] advice" help them negotiate a majority-White academic world (p. 537). Therefore, some studies have concluded that UR mentors of underrepresented 
students require heightened attentiveness to empathy, emotional output, and long-term investment in the relationship (Kendricks et al., 2013; Schwartz, 2011; Wilson et al., 2012).

\section{Salient Practice \#5: Build Community Among Members of the Team}

The fifth salient practice is for UR mentors to build community among members of the research team. In addition to fostering appropriate social-emotional ties with their undergraduate researchers, mentors who work with more than one student at a time often help build trusting interpersonal relationships among the team members. Faculty mentors have noted the benefits of regular meetings for a research team, so all parties know what has been accomplished and what is next in the research process (Bowman \& Stage, 2002; Buddie \& Collins, 2011). While one-on-one mentoring by a faculty member is associated with the highest impact for students (Kuh, 2008; Lopatto, 2003), the reality is that many students gain research experience in a tiered model, under the mentorship of post-docs, graduate students, and/or more experienced undergraduate peers; intentionally building community among the team members is well worthwhile (Edgcomb et al., 2010; Edwards et al., 2011; Dolan \& Johnson, 2009; Harrison, Dunbar, Mageeney, \& Lopatto, 2010; Jordan \& Brooks, 2013; Mahlab, 2010; Sloane, 2010). Peer and near-peer-mentoring approaches to UR spread the benefits of immersive mentored research across a greater number of students. Such approaches benefit the students being mentored and those doing the mentoring as well. In guiding each other, peers and near-peers learn the content and skills more deeply and may even develop their own pedagogy. Students mentored in a tiered team have reported appreciating a supportive environment for learning. Peer and near-peer mentors accommodated different learning styles, created a participatory learning environment, helped to develop undergraduates' critical-thinking and problem-solving skills, and were seen as approachable.

In addition to facilitating clear, organized, regular meetings for the team and intentionally establishing tiered mentoring opportunities, faculty mentors who plan informal activities outside of work time may help maintain students' interest in the research (Bender, Webster, \& Blockus, 2008) and promote a sense of community, which has been tied to student success in UR (Nagda, Gregerman, Jonides, von Hippel, \& Lerner, 1998). Engagement in group activities around a common interest have helped small and large groups of undergraduate researchers connect with each other and their faculty, graduatestudent, and/or postdoctoral-fellow mentors at different types of institutions (Bender et al., 2008). In US institutions, for example, the activities have included field trips, talent shows, and sports and games (Bender et al., 2008).

\section{Salient Practice \#6: Dedicate Time to One-On-One, Hands-On Mentoring}

Sixth among the salient practices is dedicating time to one-on-one, hands-on mentoring, even when mentoring a group of researchers. Cox and Androit's (2009) comparative study of student research skills from both the students' and mentors' perspectives pointed to the importance of hands-on mentoring practices. Students who spent less time with their mentor rated their own abilities higher than did students who spent more time, "operating under false assumptions that they were making satisfactory progress as researchers" (p. 34). When evaluating student abilities on a variety of tasks, faculty 
mentors consistently rated students lower than the students themselves did, but student ratings were more closely aligned with mentors when they spent more time with their mentors. The vital importance to students of time with their faculty mentors was a key finding by Behar-Horenstein et al. (2010). Their study revealed a discrepancy between what faculty reported (e.g. weekly meetings, open-door policies) and what students described in terms of time with their mentors. The small sample of students said they wanted more time with their faculty mentors for guidance and advice (Behar-Horenstein et al., 2010).

Similar findings about the value of time-intensive, hands-on mentoring have been reported in the literature for two decades. Cortinas, Schneider, Straka, Beasley, and Machacek (1996) found that the success of their National Science Foundation (NSF) Research Experience for Undergraduates (REU) was due largely to the "significant commitment" of mentors working closely with students. Shellito et al. (2001) reported that student learning and time spent with their mentor during a research experience were strongly related. In fact, students who spent little one-on-one time with their mentors expressed resentment about their research experience (Shellito et al., 2001).

\section{Salient Practice \#7: Increase Student Ownership Over Time}

The seventh salient practice of UR mentoring is to increase student ownership of the research over time. Johnson and Harreld (2012) found that by investing time in one-on-one mentoring (the sixth salient practice), mentors helped students gain confidence in their ability to do the work and develop independence. One student reported after a group research study in history that their mentor "was always ready to help us with our many difficulties," so "the team finally arrived at the point where we were selfsufficient” (Johnson \& Harreld, 2012, p. 370).

Shore's (2005) review of UR mentoring practices indicated that successful mentors have approached their interactions with mentees as with those with a junior colleague. Several researchers have advocated for UR environments in which all students (a) understand how their tasks relate to the larger project goals, (b) feel welcome to provide opinions about the work, (c) are listened to with patience and openness, (d) become more autonomous as they are given ownership of specific tasks and important aspects of the overall project, and (e) do work that will ultimately help them clarify and prepare for their career goals (Benson, 2002; Craig, 1999; Mabrouk \& Peters, 2000; Merkel \& Baker, 2002; National Academy of Sciences, National Academy of Engineering, Institute of Medicine, 1997; Shellito et al., 2001; Shore, 2005). The experience becomes transformative for the undergraduate researchers when they have a sense of ownership in the project (Laursen et al., 2010; Malachowski, 1996).

Encouraging student investment in a collaborative project promotes shared responsibility as well as shared power (González, 2006). Rather than simply giving advice and dispensing their knowledge, effective mentors have been said to share power by advocating for students' needs and goals (González, 2006). Researchers at the National Academy of Sciences, National Academy of Engineering, Institute of Medicine (1997) made the case in one of the earliest publications on UR mentoring that mentors should resist the temptation of holding their power over undergraduates. Instead, mentors were urged to ask for feedback from students about their mentoring, reflect on what they learn, and use student feedback to try to improve their mentoring and the environment for 
student-researchers (Gray, 2000; National Academy of Sciences, National Academy of Engineering, Institute of Medicine, 1997; Shore, 2005).

Power sharing with undergraduate researchers has been discussed most often in the literature about mentoring underrepresented minority students. Davis (2007) urged mentors to take a collaborative approach to including students of color in their work, as opposed to adopting the individualistic attitudes that prevail in some academic settings. By intentionally including diverse voices and experiences, successful mentors have benefited their own careers as well as their students' advancement (Davis, 2007; González, 2006).

\section{Salient Practice \#8: Support Students' Professional Development through Networking and Explaining Norms of the Discipline}

The eighth salient practice in the literature about UR mentoring is supporting students' professional development through networking and explaining the norms of the discipline. For students to become invested in the work and responsible for their roles in the research or creative process, the literature suggests it is important for mentors to foster an environment that will allow them to develop professionally. A primary means of professional development is providing networking opportunities for students such as introducing them to colleagues on campus and at professional conferences (Mabrouk, 2009; Mabrouk \& Peters, 2000; National Academy of Sciences, National Academy of Engineering, Institute of Medicine, 1997; Shore, 2005). Mabrouk (2009) found that students attending a conference reported that the most valuable experiences were informal activities such as discussions held in coffee shops and other off-campus sites that allowed them to network; such conversations were identified as even more beneficial than presenting their research. Mabrouk recommended that mentors make the introductions and facilitate the initial interactions.

Professional socialization provided by a faculty mentor has been shown to be even more significant for underrepresented minority students and first-generation students. First-generation students reported wanting, first and foremost, UR mentors that are experts in their field who could provide access to networking opportunities and to wellrespected and powerful connections (Ishiyama, 2007; Mekolichick \& Bellamy, 2012; Mekolichick \& Gibbs, 2012). Effective mentors were said to expand students' networks by introducing them to others in the field; they helped students navigate the unwritten rules and norms of the profession; and they wrote strong, specific, substantive letters of recommendation (Campbell \& Campbell, 2007; Davis, 2007) - providing access to professional opportunities that are otherwise very difficult to obtain for students without family or friends with experience in higher education.

\section{Salient Practice \#9: Create Intentional Opportunities for Peers and Near-Peers to Learn Mentoring Skills}

Ninth among salient practices is for faculty mentors to create intentional opportunities for peers and near-peers to learn mentoring skills, i.e. to involve students in the practice of UR mentoring. In the context of peer-mentoring scenarios, the function of a peer mentor holds many similarities to that of a faculty mentor, including the creation of a sense of community among the researchers, guiding students to make deep connections, 
role-modeling characteristics of a successful researcher, and acknowledging the need to address different learning styles (Mahlab, 2010; Packard, Marciano, Payne, Bledzki, \& Woodard, 2014). However, there are significant training implications for developing the capabilities of first-time peer or near-peer mentors. The University of Wisconsin (Madison) training program Entering Mentoring has been used in many institutions to train both graduate students and faculty (Pfund et al., 2006). Packard et al. (2014) found that the ideal peer-mentoring setting is one in which the faculty member has made clear to all involved the student mentor's role of authority in the group. Dolan and Johnson (2009) revealed that positive mentoring relationships involving graduate students required clear boundaries, especially where there were overlaps between faculty and graduate students mentoring the same undergraduate. As a result of recognizing the potential for duplication of the mentoring role between faculty and graduate students, some institution-wide schemes have evolved in a different direction so that the graduate students offer a mentoring role that is different from that of faculty. Sloane (2010) described this shift in philosophy in one university mentoring program as a result of recognition that the student mentors had no power to assess students' work and that they were not content experts. Their responsibilities therefore changed from trying to replicate the role of a faculty mentor to serving as a facilitator of scholarly thinking.

The role of faculty in the peer-mentoring process has varied according to the aims of the program and the degree to which student mentors were acting as a replacement for faculty rather than enhancing what faculty do as mentors. Overseeing the research work of a team with diverse backgrounds and levels of experience has been seen in the literature as a core capability. Faculty mentoring practices mostly involved the design and management and delegation of mentoring to graduate and undergraduate peer mentors. The implications for faculty of Dolan and Johnson's (2009) research, where mentors were graduates and postdoctoral students, are threefold: (a) Make an informed decision on when to involve a graduate student in mentoring, so that this is an intentional practice. Edwards et al. (2011) suggested it is possible that as a result of being mentored by a graduate student rather than a faculty member undergraduate mentees understood better what they do not know (p. 310). (b) Focus time with graduate mentors and undergraduate mentees at the start of the dyad and frame challenges as learning opportunities at this early stage. (c) Stress to the graduate mentors the learning benefits that they will accrue from the process, over and above any instrumental gains that may serve as a primary motivation. The role of faculty was therefore to help the peer/near-peer mentors think through and articulate their learning. Pfund et al. (2006) highlighted the importance of mentoring practices oriented to personal and emotional support; in addition to assessing students' understanding, their practices included discussions of diversity, how to foster mentees' autonomy, and the importance of showing interest in mentees as individuals by being available, an attribute echoed by Mabrouk and Peters (2000).

\section{Salient Practice \#10: Encourage and Guide Students through the Dissemination of their Findings}

The 10th salient practice of UR mentors is to encourage and guide students through the dissemination of their findings. Several researchers have focused on how mentors can help students disseminate research findings in oral and written form such as conference presentations, research reports, and journal articles (Bowman \& Stage, 2002; Craig, 
1999; Mabrouk, 2009; Mabrouk \& Peters, 2000; Merkel \& Baker, 2002; Shellito et al., 2001; Shore, 2005; Spronken-Smith et al., 2013; Walkington, 2012, 2014; Walkington, Edwards-Jones, \& Gresty, 2013). As a final stage of the research process involves the dissemination of results, Laursen et al. (2010) argued that developing student understanding of the avenues for dissemination (and the processes involved in that dissemination) will allow them to develop a greater appreciation for what it means to be a researcher and scholar while, in turn, developing their oral and written communication skills. The students interviewed by Behar-Horenstein et al. (2010) emphasized the value of their mentors encouraging them to present in informal settings, such as lab-group meetings, as well as at professional meetings. Ishiyama (2007) and Mekolichick and Bellamy (2012) found that undergraduates from diverse demographic groups indicated that one of the most important actions their mentors had taken was bringing them to conferences and encouraging them to disseminate their work.

\section{Implications}

Through a narrative review of the literature, this paper has revealed 10 salient practices which form a pedagogy of mentored UR. At their core, these practices corroborate the threepronged focus of UR mentoring described by Thiry and Laursen (2011), which highlighted the need for facilitating intellectual support, personal/emotional support, and professional socialization throughout the research experience. Our outline of salient mentor practices expands upon these important themes by identifying actionable practices that can be implemented across a diverse range of contexts. The identification of these salient practices also allows for them to be used in preparing and training faculty for UR mentoring.

While the literature acknowledges the challenges associated with mentored UR in terms of faculty time, compensation, and institutional resources, few sources acknowledge the challenges posed by the changing landscape of higher education. A pedagogy for UR in the future needs to acknowledge and adapt to the way in which the context of research-based learning in universities is evolving. If UR is for all students (Healey \& Jenkins, 2009) there are implications for being able to scale up research teams while maintaining a quality experience where students feel supported emotionally as well as academically. The USA as a context for UR is perhaps atypical in that research is institutionally resourced through embedded administrative support structures, and funding is available, particularly in the sciences, to engage students in faculty research. In fact, institutional investment in UR in the USA is now so significant that the Council on Undergraduate Research recently published a "next-generation road map" to guide colleges and universities through development and expansion of UR programs (Kinkead \& Blockus, 2012). In addition, there is a long legacy of mentored UR through summer programs. In other parts of the world, universities deal with large student numbers and adopt an inclusive model such that research experiences are embedded and mainstreamed which can preclude close relationships between faculty mentor and mentee, yet all students could potentially benefit from a mentored UR experience. Opening up the number of research opportunities to a growing and more diverse student body represents a major opportunity, and commensurate challenges arise.

In addition, there are some elements of the changing nature of higher education that pose a significant challenge to the American model of mentored student research. Research and teaching are increasingly being separated as activities with a proliferation 
of short-term "teaching only" and "research only" contracts to cope with large student numbers. The increasingly short-term nature of academic contracts is leading to precariousness, and long-term research projects could be at risk. Solving complex global problems will require team-based solutions and students will need to be able to communicate across disciplines. A pedagogy of one-to-one mentoring may not be best placed to prepare students for authentic real-world research; mentoring interdisciplinary teams may require mentors to work more collaboratively.

Just as students are forming international flows as a result of increased mobility (Altbach, Reisberg, \& Rumbley, 2009), expert faculty mentors may become more mobile as institutions form international collaborations. One evolving solution could involve virtual laboratories where student research teams are dispersed across the globe and technology is used to mediate the communication between mentees and mentors.

We therefore propose these 10 practices as a pedagogy for current mentoring relationships and will endeavor to explore, through our future research, methods in which mentoring relationships are changing in the face of new challenges and developments in higher education and how each of these practices may respond to the changing landscape in our institutions and national systems.

\section{Disclosure statement}

No potential conflict of interest was reported by the authors.

\section{Funding}

This work was supported by Elon University's Center for Engaged Learning.

\section{Notes on contributors}

Jenny Olin Shanahan, $\mathrm{PhD}$, is the director of Undergraduate Research at Bridgewater State University in Massachusetts. She serves as an executive board member of the Council on Undergraduate Research (CUR) and a CUR councilor in the Undergraduate Research Program Directors Division. She has co-edited two books on UR in the arts and humanities and has authored several articles and book chapters on research in the curriculum. She is a regular presenter of faculty workshops, plenaries, and keynote addresses on UR and other high-impact practices, especially for under-represented students.

Elizabeth Ackley-Holbrook, $\mathrm{PhD}$, is an assistant professor in the Department of Health and Human Performance at Roanoke College. Her research interests involve physical activity epidemiology, community-based participatory research, and special populations. She has authored 13 refereed journal articles and 32 presentations in her fields of study.

Eric Hall, $\mathrm{PhD}$, is a professor of Exercise Science at Elon University. His research interests include the influence of physical activity on mental health as well as the impact of concussions on collegiate student-athletes. He has published over 40 journal articles and book chapters.

Kearsley Stewart, $\mathrm{PhD}$, is associate professor of Global Health and Cultural Anthropology at Duke University where she teaches undergraduate and graduate courses in HIV/AIDS narratives, ethics of infectious disease control, global health research ethics, and qualitative research methods. Her primary research focuses on the ethics of HIV/AIDS research and antiretroviral treatment in Africa. 
Helen Walkington, $\mathrm{PhD}$, is the principal lecturer for the Student Experience at Oxford Brookes University in the UK. She carries out research into higher education pedagogy, in addition to disciplinary research in geography. Walkington has published 34 refereed journal articles, a monograph and a book, 11 book chapters, and given 35 International conference presentations.

\section{References}

Abdel-Qader, I. (2004). An undergraduate research mentoring model in digital signal and image processing. International Journal of Electrical Engineering Education, 41, 146-157.

Alamodi, A. A., Abu-Zaid, A., Anwer, L. A., Khan, T. A., Shareef, M. A., Shamia, A. A., ... Yaginuddin, A. (2014). Undergraduate research: An innovative student-centered committee from the Kingdom of Saudi Arabia. Medical Teacher, 36, S36-S42.

Altbach, P. G., Reisberg, L., \& Rumbley, L. (2009). Trends in global higher education: Tracking an academic revolution. Chestnut Hill, MA: Boston College Center for International Higher Education.

Behar-Horenstein, L. S., Roberts, K. W., \& Dix, A. C. (2010). Mentoring undergraduate researchers: An exploratory study of students' and professors' perceptions. Mentoring \& Tutoring: Partnership in Learning, 18, 269-291.

Bender, C., Webster, M., \& Blockus, L. (2008). Creating community in your undergraduate research program: It doesn't happen spontaneously! CUR Quarterly, 28, 8-12.

Benson, E. (2002). Learning by doing: Four keys to fostering undergraduate research in your laboratory. Monitor in Psychology, 33, 42-44.

Bowman, M. H., \& Stage, F. K. (2002). Personalizing the goals of undergraduate research: Implementing three types of goals. Journal of College Science Teaching, 32, 120-125.

Boyer Commission on Educating Undergraduates in the Research University. (1998). Reinventing undergraduate education: A blueprint for America's research universities. Stony Brook, NY: State University of Stony Brook.

Brandt, L. S. E. \& Hayes, J. L. (2012). Broader impacts of undergraduate research at a community college: Opening doors to new ideas. CUR Quarterly, 33, 17-21.

Brownell, J. E., \& Swaner, L. E. (2010). Five high-impact practices: Research on learning outcomes, completion, and quality. Washington, DC: Association of American Colleges and Universities.

Brush, E., Cox, M., Harris, A., \& Torda, L. (2010). Undergraduate research as faculty development. CUR Quarterly, 31, 11-16.

Buddie, A. M., \& Collins, C. L. (2011). Faculty perceptions of undergraduate research. Perspectives on Undergraduate Research Mentoring, 1(1). Retrieved from http://blogs.elon.edu/purm/ 2011/10/11/faculty-perceptions-of-undergraduate-research-purm-1-1/

Campbell, D. E., \& Campbell, T. A. (2007). Outcomes of mentoring at-risk college students: Gender and ethnic matching effects. Mentoring \& Tutoring, 15, 135-148.

Cooley, E. L., Garcia, A. L., \& Hughes, J. L. (2008). Undergraduate research in psychology at liberal arts colleges: Reflections on mutual benefits for faculty and students. North American Journal of Psychology, 10, 463-472.

Cortinas, J. V., Schneider, J. M., Straka, J. M., Beasley, W. H., \& Machacek, C. M. (1996). Educational affairs. Bulletin of the American Meteorological Society, 77, 2925-2936.

Corwin, L. A., Graham, M. J., \& Dolan, E. L. (2015). Modeling course-based undergraduate research experiences: An agenda for future research and evaluation. CBE - Life Sciences Education, 14, 1-13.

Cox, M. F., \& Androit, A. (2009). Mentor and undergraduate student comparisons of students' research skills. Journal of STEM Education, 10, 31-39.

Craig, N. C. (1999). The Joys and trials of doing research with undergraduates. Journal of Chemical Education, 76, 595-598.

Crawford, I., Orel, S., \& Shanahan, J. O. (Eds.). (2014). How to get started in arts and humanities research with undergraduates. Washington, DC: Council on Undergraduate Research.

Crawford, I., \& Shanahan, J. O. (2014). Undergraduate research in the arts and humanities: Challenges, opportunities, and rewards. In I. Crawford, S. Orel, \& J. O. Shanahan (Eds.), How 
to get started in arts and humanities research with undergraduates (pp. 1-11). Washington, DC: Council on Undergraduate Research.

Davis, D. J. (2007). Access to academe: The importance of mentoring to black students. The Negro Education Review, 58, 217-231.

DeVries, D. N. (2001). Undergraduate research in the humanities: An oxymoron? CUR Quarterly, $21,153-153$.

Dolan, E., \& Johnson, D. (2009). Toward a holistic view of undergraduate research experiences: An exploratory study of impact on graduate/postdoctoral mentors. Journal of Science Education and Technology, 18, 487-500.

Edgcomb, M. R., Antola-Crowe, H. A., Rice, J. D., Morris, S. J., Wolffe, R. J., \& McConnaughay, K. D. (2010). Peer and near peer mentoring: Enhancing learning in summer research programmes. CUR Quarterly, 31, 18-25.

Edwards, T. M., Smith, B. K., Watts, D. L., Germain-Aubrey, C. C., Roark, A. M., Bybee, S. M., ... Guillette, L. J. (2011). Group-advantaged training of research (GATOR): A metamorphosis of mentorship. BioScience, 61, 301-311.

Elgren, T., \& Hensel, N. (2006). Undergraduate research experiences: Synergies between scholarship and teaching. Peer Review, 8, 4-7.

Elrod, S., Husic, D., \& Kinzie, J. (2010). Research and discovery across the curriculum. Peer Review, 12, 4-8.

Falconer, J., \& Holcomb, D. (2008). Understanding undergraduate research experiences from the student perspective: A phenomenological study of a summer student research program. College Student Journal, 42, 869-878.

FitzGerald, W., \& Midiri, N. (2013). But is it really research? Undergraduate anxieties in the humanities. Perspectives on Undergraduate Research Mentoring, 2(2). Retrieved from http:// blogs.elon.edu/purm/2013/04/12/previous-issue-p-u-r-m-2-2/

Gafney, L. (2005). The role of the research mentor/teacher. Journal of College Science Teaching, $24,52-56$.

Gandara, P., \& Maxwell-Jolly, J. (1999). Priming the pump: Strategies for increasing achievement of underrepresented minority graduates. New York, NY: The College Board.

Gillies, S. L. \& Marsh, S. (2013). Doing science research at an undergraduate university. International Journal of Arts and Sciences, 6, 379-390.

González, C. (2006). When is a mentor like a monk? Academe, 92, 29-32.

Graham, D., Hempstead, J., \& Couchman, R. (2012). Forging a template for undergraduate collaborative research: A case study. Creative Education, 03, 859-865.

Gray, G. (2000). Producing results: Effective management and mentoring in academic labs. AWIS Magazine, 29, 14-18.

Gregerman, S. R. (2009). Filling the gap: The role of undergraduate research in student retention and academic success. In M. K. Boyd \& J. L. Wesemann (Eds.), Broadening participation in undergraduate research: Fostering excellence and enhancing the impact (pp. 245-256). Washington, DC: Council on Undergraduate Research.

Guterman, L. (2007, August 17). What good is undergraduate research, anyway? Chronicle of Higher Education, 53, 11-12.

Hakim, T. (1998). Self-assessment of undergraduate research: Reactions and student perspectives. CUR Quarterly, 18, 189-192.

Handelsman, J., Pfund, C., Lauffer, S. M., \& Pribbenow, C. M. (2005). Entering mentoring: A seminar to train a new generation of scientists. Madison, WI: University of Wisconsin Press.

Harrison, M., Dunbar, D., Mageeney, C., \& Lopatto, D. (2010). Peer mentoring in an introductory biology laboratory. CUR Quarterly, 31, 9-14.

Healey, M., \& Jenkins, A. (2009). Developing undergraduate research and inquiry. York: Higher Education Academy.

Healey, M., Jenkins, A., \& Lea, J. (2014). Developing research-based curricula in college-based higher education. York: Higher Education Academy.

Hensel, N. (2012). Characteristics of excellence in undergraduate research. Washington, DC: Council on Undergraduate Research.

Hensel, N. H., \& Cejda, B. D. (Eds.). (2014). Tapping the potential of all: Undergraduate research in community colleges. Washington, DC: Council on Undergraduate Research. 
Ibnouf, A., Dou, L., \& Knight, J. (2014). The evolution of Qatar as an education hub: Moving to a knowledge-based economy. In J. Knight (Ed.), International Education Hubs (pp. 43-61). Dordrecht: Springer Science and Business Media.

Ishiyama, J. (2007). Expectations and perceptions of undergraduate research mentoring: Comparing first generation, low income White/Caucasian and African American students. College Student Journal, 41, 540-549.

Jenkins, A., \& Healey, M. (2010). Undergraduate research and international initiatives to link teaching and research. CUR Quarterly, 30, 36-42.

Johnson, B. A., \& Harreld, D. J. (2012). Nurturing independent learning in the undergraduate student in History: A faculty-student mentoring experience. Mentoring \& Tutoring: Partnership in Learning, 20, 361-378.

Jones, M. T., Barlow, A. E. L., \& Villarejo, M. (2010). Importance of undergraduate research for minority persistence and achievement in biology. The Journal of Higher Education, 81, $82-115$.

Jones, R. M. \& Davis, S. N. (2014). Assessing faculty perspectives on undergraduate research: Implications from studies of two faculties. CUR Quarterly, 34, 37-42.

Jordan, R. C., \& Brooks, W. R. (2013). Graduate students as mentors to undergraduates in research: A discussion of benefits and limitations. Perspectives on Undergraduate Research Mentoring, 3(1). Retrieved from http://blogs.elon.edu/purm/2013/10/22/previous-issue-purm-3$1 /$

Kardash, C. M. (2000). Evaluation of undergraduate research experience: Perceptions of undergraduate interns and their faculty mentors. Journal of Educational Psychology, 92, 191-201.

Kasprisin, C. A., Boyle Single, P., Single, R. M., \& Muller, C. B. (2003). Building a better bridge: Testing e-training to improve e-mentoring programmes in higher education. Mentoring \& Tutoring: Partnership in Learning, 11, 67-78.

Kendricks, K. D., Nedunuri, K. V., \& Arment, A. R. (2013). Minority student perceptions of the impact of mentoring to enhance academic performance in STEM disciplines. Journal Of STEM Education: Innovations \& Research, 14, 38-46.

Kinkead, J., \& Blockus, L. (Eds.). (2012). Undergraduate research offices \& programs: Models and practices. Washington, DC: Council on Undergraduate Research.

Kinzie, J., Gonyea, R., Shoup, R., \& Kuh, G. D. (2008). Promoting persistence and success of underrepresented students: Lessons for teaching and learning. In J. M. Braxton (Ed.), The role of the classroom in college student persistence (pp. 21-38). San Francisco, CA: Jossey-Bass.

Klos, N. Y., Shanahan, J. O., \& Young, G. (Eds.). (2011). Creative inquiry in the arts and humanities: Models of undergraduate research. Washington, DC: Council on Undergraduate Research.

Kuh, G. (2008). High-impact educational practices: What they are, who has access to them, and why they matter. Washington, DC: Association of American Colleges and Universities.

Kuh, G., \& O’Donnell, K. (2013). Ensuring quality and taking high-impact practices to scale. Washington, DC: Association of American Colleges and Universities.

Laursen, S., Hunter, A., Seymour, E., Thiry, H., \& Melton, G. (2010). Undergraduate research in the sciences: Engaging students in real science. San Francisco, CA: Josey-Bass.

Levenson, C. (2010). Enhancing undergraduate research in the arts and humanities. Peer Review, $12,13-15$.

Linn, M. C., Palmer, E., Baranger, A., Gerard, E., \& Stone, E. (2015). Undergraduate research experiences: Impact and opportunities. Science, 347, 627-633.

Locks, A. M., \& Gregerman, S. R. (2008). Undergraduate research as an institutional retention strategy: The University of Michigan model. In R. Taraban \& R. L. Blanton (Eds.), Creating effective undergraduate programs in science: The transformation from student to scientist (pp. 11-32). New York, NY: Teachers College Press.

Lopatto, D. (2003). Essential features of undergraduate research. CUR Quarterly, 24, 139-142.

Lopatto, D. (2004). Survey of undergraduate research experiences (SURE): First findings. Cell Biology Education, 3, 270-277.

Lopatto, D. (2010). Undergraduate research as a high-impact student experience. Peer Review, 12, $2-30$.

Lown, J. (1993). Involving undergraduate students in faculty research. Advancing the Consumer Interest, 5, 29-31. 
Mabrouk, P. A. (2003). Research learning contracts: A useful tool for facilitating successful undergraduate research experiences. CUR Quarterly, 21, 26-30.

Mabrouk, P. A. (2009). Survey study investigating the significance of conference participation to undergraduate research students. Journal of Chemical Education, 86, 1335-1340.

Mabrouk, P. A., \& Peters, K. (2000). Student perspectives on undergraduate research experiences in chemistry and biology. CUR Quarterly, 21, 25-33.

Mahlab, M. (2010). CUR focus: Who benefits? Peer mentors at Grinnell College. CUR Quarterly, $31,7-10$.

Malachowski, M. (1996) The mentoring role in undergraduate research projects. CUR Quarterly, 17, 91-93, 105-106.

McDorman, T. (2004). Promoting undergraduate research in the humanities: Three collaborative approaches. CUR Quarterly, 25, 39-42.

Mekolichick, J., \& Bellamy, J. (2012). Research experiences for undergraduates: Student presenter's perceptions of mentoring and conference presentation by college generational status and sex. Perspectives on Undergraduate Research Mentoring, 1.1.

Mekolichick, J., \& Gibbs, M. K. (2012). Understanding college generational status in the undergraduate research experience. CUR Quarterly, 33, 40-46.

Merkel, C. A., \& Baker, S. M. (2002). How to mentor undergraduate researchers. Washington, DC: Council on Undergraduate Research.

Moore, D. B., Dueweke, A., Newton, C. R., \& Stevens-Russ, R. (2005). Mentoring students in professional-quality science communication. CUR Quarterly, 25, 118-121.

Nagda, B. A., Gregerman, S., Jonides, J., von Hippel, W., \& Lerner, J. S. (1998). Undergraduate student-faculty research partnerships affect student retention. Review of Higher Education, 22, $55-72$.

National Academy of Sciences, National Academy of Engineering, Institute of Medicine. (1997). Adviser, teacher, role model, friend: On being a mentor to students in science and engineering. Washington, DC: National Academies Press.

Osborn, J., \& Karukstis, K. (2009). The benefits of undergraduate research, scholarship, and creative activity. In M. K. Boyd \& J. L. Wesemann (Eds.), Broadening participation in undergraduate research: Fostering excellence and enhancing the impact (pp. 41-53). Washington, DC: Council on Undergraduate Research.

Packard, B. W., Marciano, V. N., Payne, J. M., Bledzki, L. A., \& Woodard, C. T. (2014). Negotiating peer mentoring roles in undergraduate research lab settings. Mentoring \& Tutoring: Partnership in Learning, 22, 433-445.

Padmaja, A., Laxmi Ramana, V. S. V., Reddy, P. R. (2015). Importance of research at undergraduate level. Proceedings of the International Conference on Transformations in Engineering Education, 631-632. Retrieved from http://link.springer.com/chapter/10.1007/978-81-3221931-6 101

Pfund, C., Pribbenow, C. M., Branchaw, J., Miller-Lauffer, S., \& Handelsman, J. (2006). Professional skills: Enhanced: The merits of training mentors. Science, 311, 473-474.

van der Rijst, R. M., \& Visser-Wijnveen, G. J. (2011). Undergraduate research and inquiry in the Netherlands. CUR Quarterly, 32, 32-36.

Sandover, S., Partridge, L., Dunne, E., \& Burkill, S. (2012). Undergraduate researchers change learning and teaching: A case study in Australia and the United Kingdom. CUR Quarterly, 33, $33-39$.

Schantz, M. (2008). Undergraduate research in the humanities: Challenges and prospects. CUR Quarterly, 29, 26-29.

Schultz, J. R. (2001). The transformational process of mentoring. CUR Quarterly, 22, 72-73.

Schwartz, J. (2011). Faculty as undergraduate research mentors for students of color: Taking into account the costs. Science Education, 96, 527-542.

Shanahan, J. O., Liu, X., Manak, J., Miller, S. M., Tan, J., \& Yu, C. W. (2015). Research-informed practice, practice-informed research: The integral role of undergraduate research in professional disciplines. CUR Quarterly, 35, 6-16.

Shellito, C., Shea, K., Mueller-Solger, A., \& Davis, W. (2001). Successful mentoring of undergraduate researchers: Tips for creating positive student research experiences. Journal of College Science Teaching, 30, 460-464. 
Shore, C. (2005). Toward recognizing high-quality faculty mentoring of undergraduate scholars. Journal of Excellence in College Teaching, 16, 111-136.

Showman, A., Cat, L. A., Cook, J., Holloway, N., \& Wittman, T. (2013). Five essential skills for every undergraduate researcher. CUR Quarterly, 13, 16-20.

Sloane, A. (2010). Peer teaching and mentoring: The case of undergraduate research fellows. CUR Quarterly, 31, 11-17.

Spronken-Smith, R. A., Brodeur, J. J., Kajaks, T., Luck, M., Myatt, P., Verburgh, A., ... Wuetherick, B. (2013). Completing the research cycle: A framework for promoting dissemination of undergraduate research and inquiry Teaching \& Learning Inquiry. The ISSOTL Journal, $1,105-118$.

Thiry, H., \& Laursen, S. L. (2011). The role of student-advisor interactions in apprenticing undergraduate researchers into a scientific community of practice. Journal of Science Education and Technology, 20, 771-784.

Thorsheim, H., LaCost, H., \& Narum, J. L. (2010). Peer mentoring of undergraduate research in community colleges: A "transplantable" model for workshops. CUR Quarterly, 31, $26-32$.

Walkington, H. (2012). Developing dialogic learning space: The case of online undergraduate research journals. Journal of Geography in Higher Education, 36, 547-562.

Walkington, H. (2014). Quality enhancement of undergraduate research - further strategies to increase student engagement in research dissemination Brookes E-journal of Learning and Teaching, 6(1). Retrieved from http://bejlt.brookes.ac.uk/paper/quality-enhancement-of-under graduate-research-further-strategies-to-increase-student-engagement-in-research-dissemination/

Walkington, H., Edwards-Jones, A., \& Gresty, K. (2013). Strategies for widening students' engagement with undergraduate research journals. CUR Quarterly, 34, 24-30.

Wang, G., \& Wang, H. (2008). Strategy and practice of undergraduate research competence building in research universities in China. Tsinghua Journal of Education, 29, 44-48.

Wayment, H. A., \& Dickson, K. L. (2008). Increasing student participation in undergraduate research benefits students, faculty, and department. Teaching of Psychology, 35, 194-197.

Wenzel, T. J. (1997). What is undergraduate research? CUR Quarterly, 17, 163.

Wilson, Z. S., Holmes, L., deGravelles, K., Sylvain, M. R., Batiste, L., Johnson, M., ... Warner, I. M. (2012). Hierarchical mentoring: A transformative strategy for improving diversity and retention in undergraduate STEM disciplines. Journal of Science Education and Technology, $21,148-156$.

Yaffe, K., Bender, C., \& Sechrest, L. (2012). What is a mentor? CUR Quarterly, 33, 34-39.

Yuhao, C. (2014). Student development in undergraduate research programs in China: From the perspective of self-authorship. International Journal of Chinese Education, 3, 53-73. 